\author{
Szilárd Tátrai \\ EÖTVÖS LORÁND UNIVERSITY (ELTE) / JAGIELLONIAN UNIVERSITY \\ TATRAI.SZILARD@GMAIL.COM \\ HTTPS://ORCID.ORG/OOOO-0002-1069-6676
}

\author{
Júlia Ballagó \\ EÖTVÖs LORÁND University (ELTE) / MTA RESEARCH InSTITUTE FOR LiNGUistics \\ JULIA.BALLAGO@GMAIL.COM \\ HTTPS://ORCID.ORG/OOOO-0OO2-7349-2224
}

\title{
On Socio-Cultural Situatedness in Style Attribution: A Study of Style in Hungarian
}

\begin{abstract}
Building upon the theoretical foundations of social cognitive linguistics, this paper makes the case for considering the speaker's socio-cultural situatedness in the intersubjective context of joint attention as a key factor in the process of style attribution. Specifically, socio-cultural situatedness is regarded as a crucial component of the speaker's perspective, playing a decisive role in the construal of style. In order to support this central assumption, the paper presents a two-phase empirical study of style in Hungarian. In the first phase, the authors conducted a questionnaire study to find out which everyday, intuitive labels of style give evidence of the speaker's socio-cultural situatedness. The questionnaire made use of 12 excerpts of Hungarian university seminars to elicit reflections on style attributions. In the second phase, relying on the results of the first survey, a subsequent questionnaire was conducted. The aim of the second questionnaire was to operationalize folk categories of style attested in the first phase to describe style and measure stylistic markedness. Reconsidering earlier descriptive models, we found that the folk categories of style foreground different aspects of the speaker's socio-cultural situatedness which - on a more abstract level - can be successfully described by the heuristic scientific categories of socio-cultural factors, which imply the speaker's socio-cultural attitude to different aspects of style in the recipient's interpretation. The speaker's socio-cultural attitude comprises her attitude to the formation of discourse, to the dis-
\end{abstract}


course partner, to the value of the topic, to the temporality of constructions and to the norms of the register of the discourse.

Keywords: joint attention, metapragmatic awareness, social salience, socio-cultural factors, socio-cultural situatedness, style attribution, stylistic markedness

\section{Introduction}

The paper formulates its questions and answers from the perspective of social cognitive pragmatics (see e.g. Croft 2009). In particular, from an approach that takes our social cognitive ability of joint attention as a point of departure (see Tomasello 1999; cf. Sinha 2014) for describing the meaningful functioning of language (see Verschueren 1999; Verschueren and Brisard 2009). Discourses are regarded as joint attentional scenes whose participants share their experiences about the world as they direct their attention to certain processes involving things, that is, to particular referential scenes. Linguistic cognition based on the functioning of joint attention is a human activity whose crucial feature is construal (see Langacker 1987; 2008). Accordingly, what is special about the use of linguistic symbols is the perspectival nature of their meaning. More specifically, linguistic symbols allow for highly flexible and elaborated conceptual processing of the world from various perspectives (Langacker 2008, 55-89; cf. also Sinha 2014; Verhagen 2007).

Nevertheless, linguistic symbols applied in the joint attentional scene only serve as prompts for the construal of experiences in certain ways. The speaker's perspective has a fundamental influence on the grounding of referential scenes (cf. Sanders-Spooren 1997). This perspective involves the speaker's socio-cultural situatedness (e.g. Frank 2008; Zlatev 1997; 2014) as a crucial component. Considering style attribution, it is pivotal that the speaker's socio-cultural situatedness does not exclusively involve context-dependent reference points for the identification of participants in the social world of the referential scene. More globally, this vantage point allows participants of the joint attentional scene to adjust their intersubjective construal of experiences to accessible socially grounded and culture-specific expectations concerning adequate construal of style (see Tátrai 2013). This implies that the processing of a speaker's socio-cultural situatedness - for example, understanding that the speaker talks to her teacher as a student (or to her student(s) as a teacher) about a scientific topic in a university seminar - is a key factor during style attribution, since it makes socio-cultural attitude to style an integral part of construal. Socio-cultural attitude to style may affect the following factors (Tátrai 2013, 25-27; cf. Tolcsvai Nagy 2005; 2013):

Factor 1 Discourse: speaker's attitude to the overall formation of discourse in the recipient's interpretation (e.g., sophisticated - neutral - casual)

Factor 2 Situation: speaker's attitude to her discourse partner in the recipient's interpretation (e.g., formal - neutral - informal) 
Factor 3 Value: speaker's value-based attitude to the topic of the discourse in the recipient's interpretation (e.g., value saturating - neutral - value depriving)

Factor 4 Time: speaker's attitude to the temporality of linguistic constructions in the recipient's interpretation (e.g., archaic - neutral - innovative)

Factor 5 Language variety: speaker's attitude to the norms of the register of the discourse in the recipient's interpretation (e.g., standard, slang, dialectal etc.)

The functioning of style in the dynamics of meaning generation hinges on the degree to which intersubjective construal meets, or fails to meet, relevant socio-cultural expectations (conventions) concerning the construal of style, that is, relevant stylistic schemas. Under the proposed usage-based interpretation (cf. Barlow and Kemmer 2000), the stylistic functions of a linguistic construction are always described in their discursive context, with regard to the stylistic schemas (used as orienting norms) being activated by discourse participants. In language use, stylistic schemas are open, prototype-based categories functioning in a context-sensitive and probabilistic way, anchored to typical situations, actions, topics, and associated discourse types (Tolcsvai Nagy 2005: 132-134). Consequently, style attributions made by discourse participants, are linked to the activation of stylistic schemas, and to the processing of linguistic constructions functioning as stylistic elements. When a given construction (with respect to any socio-cultural factor) is seen to comply with the typical formation associated with a certain type of situation, action, topic and discourse (i.e., it complies with the stylistic schema being activated), then its stylistic value can be regarded as neutral (unmarked). If, however, a given construction activates a stylistic schema associated with a different type of situation, action, topic or discourse as well, then its stylistic value shifts towards one or another extreme of the domain of the relevant socio-cultural factor and becomes stylistically marked.

Therefore, during the process of style attribution, the stylistic markedness of certain linguistic constructions is closely linked to their discursive, social salience (see Verschueren 1999: 173-200; cf. Smith and Mackie 2000: 66). Salience is a complex phenomenon which is characterized by prominence from the aspect of perception, entrenchment from the aspect of conceptualization and expectedness from the aspect of discourse (see Schmid 2007; Schmid and Günther 2016). The notion of social salience, which affects the degree to which the construal of linguistic constructions meets the relevant socio-cultural norms and expectations, is pertinent to style as well. Looking at the degree to which particular linguistic construals are expected or unexpected with respect to the stylistic schemas conventionalized by the community and routinized at the individual level, we may conclude that the discursive, social salience and degree of expectedness of linguistic constructions are inversely proportional. The more expected is the style of a particular construction in a given situation, the less it becomes stylistically marked, and vice versa. 
Another essential implication of the above is that the stylistic schema being activated in a given discourse is the result of abstraction from previous discursive experiences of the participants, when they were involved (as speakers, addressees, or even outside observers) in discourses carrying out similar actions or addressing similar topics. However, by virtue of the diversity of people's discursive experiences, individual speakers do not possess the speech community's repertoire of stylistic schemas in its entirety. As a result, there may be a significant gap between the goal and expectation norms of the discourse participants (cf. Sharifian 2008; 2017).

\section{Research questions}

Aiming at the harmonization of theoretical modelling with empirical research, the empirical study addresses the overarching question as to how the speaker's socio-cultural situatedness functions in style attribution. In the two-phase empirical study of Hungarian, this global question is broken down into some more specific ones:

RQ1 Which everyday, intuitive labels of style give evidence of the speaker's socio-cultural situatedness during the process of style attribution?

RQ2 Which factors of the speaker's socio-cultural situatedness are foregrounded by the expressions reflecting style attributions; which conceptual domains of particular factors are profiled by these expressions?

RQ3 What is the effect of particular socio-cultural factors on the stylistic character of the discourse, and the stylistic markedness of the applied linguistic constructions?

RQ4 How do linguistic constructions processed in the course of style attribution become stylistically marked, thus salient in the discursive context of construal?

The questions reveal that the empirical study was also inspired by a metascientific question: How may everyday, intuitive labels reflecting style attributions serve as a basis for the scientific description of style? Our point of departure was that the metapragmatic awareness of discourse participants - that is, their capability of having a reflexive attitude to particular linguistic constructions and the associated cognitive processes and socio-cultural conventions, both as speakers and recipients (cf. Verschueren 2000) - does affect style attribution, as an integral aspect of meaning generation. Relatedly, we also presumed that socio-cultural attitudes to the construal of style - in the form of metapragmatic reflections (e.g., to express myself in a sophisticated way) - could not only become objectified in their natural discursive contexts, but they might be elicited by questionnaire studies as well (cf. Bednarek 2011). 


\section{Method and data}

The investigation consisted of two consecutive questionnaire studies: the first was an open questionnaire targeted at informants' intuitive reflections on style attributions, while the second was a closed, usage-based questionnaire that built heavily on the results of the first survey. The elicited everyday labels of style indicate particular conceptual domains of socio-cultural factors in an intuitive way. For example, the expressions hétköznapi 'everyday', laza 'casual' and társalgási 'conversational' point to the same conceptual domain of the Factor of Discourse (F1), while the expressions választékos 'sophisticated' and tudományos 'scientific' indicate the opposite conceptual domain of the same Factor (F1). Since these intuitive expressions labelling style are retrieved from language users' knowledge, we considered them as folk categories. It also has to be added that the conceptual domains of particular socio-cultural factors characteristically display a polarized structure (e.g., regarding the Factor of Discourse (F1), we are able to talk about SOPHISTICATION and CASUALNESS, regarding the Factor of Situation (F2), about UNBOUNDEDNNESS and OFFICIALNESS, regarding the Factor of Value (F3), about SERIOUSNESS and IRONY).

The primary linguistic input of the empirical study was supplied by the transcribed recording of four Hungarian university seminars. From this linguistic data, we chose 12 excerpts for the purposes of the two subsequent questionnaires.

In the first step, we intended to detect how Hungarian native speaker informants would reflect on their own style attributions. Importantly, on the one hand, we were relying on the folk category of style itself, as we did not define the notion of style to informants. On the other hand, respondents were not participants (speakers or addressees) of the discourses they were asked about. However, they consistently became recipients of the discourses because they processed the style of utterances from the speaker's socio-cultural situatedness, and formulated metapragmatic reflections on the construal of style from this vantage point as well (e.g. Verschueren 1999, 187-189; 2000). Remarkably, the study did not focus on respondents' macrosocial factors (gender, age, qualification etc.) but rather on how they reflected on the speaker's socio-cultural situatedness, a key factor in style attribution. Furthermore, in the first questionnaire, we also asked informants about which linguistic constructions played a central role in their style attributions.

The first questionnaire was composed in six different versions. The task was to answer two questions related to our 12 excerpts, each supplemented with short explanatory context. The first question (Ön szerint milyen a stílusa a fenti párbeszédnek? 'In your opinion, what is the style of the dialogue above?') called upon respondents to reflect on their own style attribution, of which they were made aware by the question. Thus, answers were expressions reflecting style attributions. By the investigation of how these folk categories formed bundles, we learned about which factors of socio-cultural situatedness had been activated in particular excerpts, and - on a more general, abstract level - which socio-cultural factors had played a decisive role in particular excerpts. 
The second question of the first questionnaire (Elöző válaszát a párbeszéd mely kifejezése/kifejezései alapján fogalmazta meg? 'In your previous answer, which was(/ were) the expression(s) of the dialogue you based your answer on?') concentrated on linguistic constructions becoming stylistically marked in the course of style attributions, that is, on their social salience. In the background of the formulation of the question is the assumption that certain linguistic constructions may activate particular stylistic schemas. If the language user perceives deviation from this stylistic schema, she links it to the discursive, social salience of certain linguistic constructions. Importantly, the research was not aimed at drawing a comprehensive picture of the stylistic markedness of different construction types. It only intended to point out the stylistic relevance of social salience.

In the second questionnaire we studied the extent to which folk categories reflecting style attributions are suitable for the description of the style of a given excerpt. In this connection, we also examined the degree and quality of the stylistic markedness of linguistic constructions which proved to be stylistically relevant in the former questionnaire.

The second questionnaire made use of the same 12 excerpts as the first survey. In four versions of the total six, we highlighted a certain construction of particular excerpts according to the results of the first questionnaire with regard to the two most salient constructions. In these cases, our questions addressed the style of these constructions, while in the remaining two versions, the questions addressed the style of the entire excerpt. We prepared 5-point scales for specific socio-cultural factors, and to denominate the end- and midpoints of the scales, we used the folk categories describing stylistic markedness that had been produced in the first questionnaire. For example, to describe stylistic markedness in terms of Factor 1, we applied the scale laza, hétköznapi - átlagos, semleges - választékos, tudományos 'casual, everyday - average, neutral - sophisticated, scientific'; in terms of Factor 2, the scale bizalmas, informális - átlagos, semleges - hivatalos, formális 'direct, informal - average, neutral - official, formal' was established, etc. The task of respondents was to evaluate the style of the highlighted construction or the entire excerpts according to the supplied criteria.

Both steps of data collection were conducted with 200 informants. The mean age of respondents was 29.5 years in the first, and 33.5 years in the second questionnaire. The majority of informants were female: the first survey was recorded with 151, while the second one with 158 females. The majority of respondents (61\% and 46\%) were from the capital of Hungary. Importantly, our research makes no claim on representativity, nor does it aim for statistical significance. Instead, we intend to contribute to the elaboration of theoretical and methodological foundations for the quantitative study of style attribution. Bar charts and tables in Section 4 only give a description of our data, but we do not strive for testing statistical hypotheses. 
Pobrane z czasopisma New Horizons in English Studies http://newhorizons.umcs.pl Data: 26/04/2023 15:05:58

\section{Results}

The study investigated how socio-cultural factors concern different socio-cultural attitudes of the speaker to particular aspects of the intersubjective construal of style: (F1) to the formation of the discourse, (F2) to the discourse partner, (F3) to the value of the topic, (F4) to the temporality of linguistic constructions, and (F5) to the register of the discourse. In particular, we presumed that everyday labels of style - in the form of metapragmatic reflections - profile specific conceptual components (conceptual nodes) of particular socio-cultural factors which themselves prove to be conceptually complex.

\subsection{Expressions reflecting style attributions}

The 200 respondents of the first questionnaire used 268 different expressions in total for making style attributions. Figure 1 presents the 24 most frequent expressions which occurred in at least 10 responses.

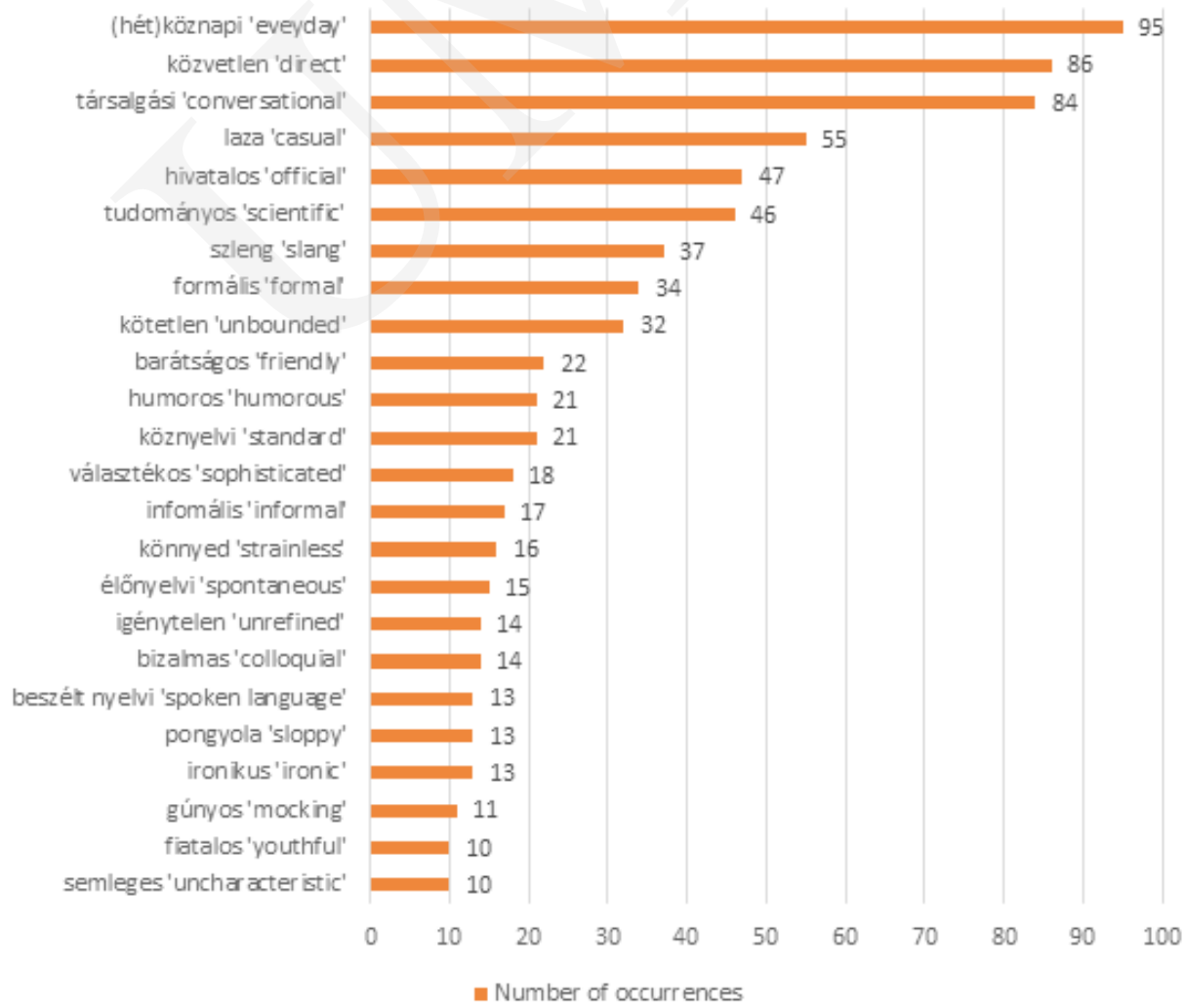

Figure 1. The most frequent expressions reflecting style attributions 
Among the most frequent expressions, the largest part of our data profiles two socio-cultural factors of style, the Factor of Discourse (F1) and Situation (F2), but further Factors (F3, F5 and F4) are also foregrounded by some frequently occurring expressions. Importantly, socio-cultural factors are not a priori, nor objectively presumed categories; rather, they are heuristic categories which are classified on a higher level of abstraction compared to intuitive expressions reflecting style attributions. Factor 1, that is, socio-cultural attitude to the overall formation of discourse is foregrounded by the following expressions: hétköznapi 'everyday' (95 occurrences), társalgási 'conversational' (84), tudományos 'scientific' (46) and laza 'casual' (55) among others. The categories profiling Factor 2 are, for instance, közvetlen 'direct' (86), barátságos 'friendly' (22), informális 'informal' (17), and hivatalos 'official' (47), formális 'formal' (34) which foreground evaluations of how the speaker construes her interpersonal attitude to the discourse partner. Certain folk categories indicate Factor 3, such as humoros 'humorous' (21), ironikus 'ironic' (13) and gúnyos 'mocking' (11), expressing the speaker's value-based attitude to the topic of the discourse. Some expressions highlight Factor 5: they are folk categories such as szleng 'slang' (37) and köznyelvi 'standard' (21) giving evidence of the speaker's socio-cultural attitude to the norms of the register of the discourse. Finally, it is probably due to the basic character of the excerpts used as primary linguistic input that Factor 4, that is, socio-cultural attitude to the temporality of linguistic constructions was not profiled - in this regard, fiatalos 'youthful' (10) is the only exception among the most frequent folk categories.

In summary, the arrangement of expressions labelling style - as retrieved from language users' knowledge - seem to be describable by the scientific categories of socio-cultural factors, since these expressions profile particular conceptual domains of socio-cultural factors in an intuitive way. This explains why the above bundles of folk categories coincide with the more abstract categories of socio-cultural factors.

Regarding the arrangement of intuitive expressions reflecting style attributions, two essential statements have to be made. Firstly, the heuristic scientific categories of socio-cultural factors are open, prototype-based categories; this implies that a particular intuitive expression may prove to be a more or less prototypical instance of a certain category. For example, the expressions vicces 'comic' (7), lekezelö 'condescending' (8) and lenézö 'disdainful' (5) suggest an overlap between the Factors of Situation (F2) and Value (F3), while beszélt nyelvi 'spoken language' (13), szakmai 'professional' (8), köznyelvi 'standard' (21) and szaknyelvi 'jargon' (9) highlight that there is a close relation between the Factor of Discourse (F1) and Language variety (F5).

Secondly, within the scope of particular socio-cultural factors, certain folk categories are tightly connected, which points to the network structure of the conceptual domains associated with socio-cultural factors. This statement can be illustrated with the conceptual nodes uncovered by expressions profiling Factor 2. Concerning the Factor of Situation, the labels hivatalos 'official' (47), formális 'formal' (34), félhivatalos 'semi-formal' (8) and informális 'informal' (17) highlight the level of formality of the situation, which accordingly proves to be an essential conceptual node of the Factor. 
Pobrane z czasopisma New Horizons in English Studies http://newhorizons.umcs.pl Data: 26/04/2023 15:05:58

On Socio-Cultural Situatedness in Style Attribution: A Study of Style in Hungarian

Table 1. Classification of folk categories reflecting style attributions according to the heuristic scientific categories of socio-cultural factors (Expressions occurring at least in 5 responses)

\begin{tabular}{|c|c|c|c|c|}
\hline Discourse & Situation & Value & Language variety & Time \\
\hline (hét) köznapi (95) & közvetlen (86) & humoros (21) & szleng (37) & fiatalos (10) \\
\hline 'everyday' & 'direct' & 'humorous' & 'slang' & 'youthful' \\
\hline társalgási (84) & hivatalos (47) & ironikus (13) & köznyelvi (21) & \\
\hline 'conversational' & 'official' & 'ironic' & 'standard' & \\
\hline laza (55) & formális (34) & gúmyos (11) & szaknyelvi (9) & \\
\hline 'casual' & 'formal' & 'mocking' & 'jargon' & \\
\hline tudományos (46) & barátságos (22) & magyarázó (8) & & \\
\hline 'scientific' & 'friendly' & 'explanatory' & & \\
\hline kötetlen (32) & informális (17) & lekezelö (8) & & \\
\hline 'unbounded' & 'informal' & 'condescending' & & \\
\hline választékos (18) & bizalmas (14) & vicces (7) & & \\
\hline 'sophisticated' & 'colloquial' & 'comic' & & \\
\hline könnyed (16) & félhivatalos (8) & bizonytalan (6) & & \\
\hline 'strainless' & 'semi-formal' & 'uncertain' & & \\
\hline élönyelvi (15) & udvarias (5) & komoly (6) & & \\
\hline 'spontaneous' & 'polite' & 'solemn' & & \\
\hline igénytelen (14) & segitö(kész) (5) & tárgyilagos (5) & & \\
\hline 'unrefined' & 'helpful' & 'objective' & & \\
\hline beszélt nyelvi (13) & & tudálékos (5) & & \\
\hline 'spoken language' & & 'pedantic' & & \\
\hline pongyola (13) & & lenézö (5) & & \\
\hline 'sloppy' & & 'disdainful' & & \\
\hline \multicolumn{5}{|l|}{ szakmai (8) } \\
\hline \multicolumn{5}{|l|}{ 'professional' } \\
\hline \multicolumn{5}{|l|}{ igéryyes (8) } \\
\hline \multicolumn{5}{|l|}{ 'fastidious' } \\
\hline \multicolumn{5}{|l|}{ egyszerü (6) } \\
\hline \multicolumn{5}{|l|}{ ‘plain' } \\
\hline \multicolumn{5}{|l|}{ elöadói (6) } \\
\hline \multicolumn{5}{|l|}{ 'rhetorical' } \\
\hline \multicolumn{5}{|l|}{ magánéleti (5) } \\
\hline \multirow{2}{*}{\multicolumn{5}{|c|}{$\begin{array}{l}\text { 'private' } \\
\text { szabad (5) }\end{array}$}} \\
\hline & & & & \\
\hline \multicolumn{5}{|l|}{$\begin{array}{l}\text { szabad (5) } \\
\text { 'free' }\end{array}$} \\
\hline \multicolumn{5}{|l|}{ nem választékos (5) } \\
\hline \multicolumn{5}{|l|}{ 'not sophisticated' } \\
\hline \multicolumn{5}{|l|}{ oldott (5) } \\
\hline \multicolumn{5}{|l|}{ 'loose' } \\
\hline \multicolumn{5}{|l|}{ hanyag (5) } \\
\hline \multicolumn{5}{|l|}{ 'neg ligent' } \\
\hline \multicolumn{5}{|l|}{ összeszedetlen (5) } \\
\hline \multicolumn{5}{|l|}{ 'disorganized' } \\
\hline \multicolumn{5}{|l|}{ pontatlan (5) } \\
\hline 'imprecise' & & & & \\
\hline
\end{tabular}

Meanwhile, közvetlen 'direct' (86), barátságos 'friendly' (22) and segitökész 'helpful' (5) rather foreground another conceptual node of Factor 2, that is the quality and degree of involvement (cf. Tannen 2005). 


\subsection{Social salience in style attribution}

In the first questionnaire, we also asked informants about linguistic constructions playing a decisive role in their style attributions. More specifically, we presumed that the stylistic function of particular linguistic constructions of a discourse is substantially influenced by their relation to the activated stylistic schemas and, as a function of this, their social salience. In the present paper, we limit the demonstration of detailed results concerning particular excerpts to three selected excerpts.

(1) Excerpt "A"

A: Bármilyen tetszöleges sorrendben lehet kérdezni a problémás pontokat. Bízom benne, hogy sikerült ilyen problémás pontokat találniuk, mert én a saját jegyzékemben nagyjából kéttucatnyit szedtem össze a tananyagból.

'The problematic points can be listed in an arbitrary order. I hope that you have succeeded in finding points like this, since in my own list, I have collected about two dozen of them from the course material.'

Informants found that excerpt " $\mathrm{A}$ " had a relatively neutral style. First of all, respondents to excerpt "A" gave less unambiguous answers about the most salient expressions. As it is illustrated below by Table 2, bizom benne 'I hope that' (34\%) and kéttucatnyit 'two dozen' (24\%) were the most salient constructions. The majority of respondents highlighting bizom benne 'I hope that' (11) selected this construction because they found it lenézö 'disdainful', fölényes 'supercilious', gúnyos 'mocking' or cinikus 'cynical', that is, stylistically marked in terms of the speaker's value-based attitude to the topic of the discourse (Factor 3). With regard to kéttucatnyit 'two dozen', most respondents (9) profiled the Factor of Discourse (F1). For example, besides laza 'casual' and magánéleti 'private', tudományos 'scientific' and szónoki 'rhetorical' also occurred as opposite conceptual domains of the Factor. Furthermore, some folk categories describing the style of the two most salient constructions profile the Factor of Situation (F2): with respect to bizom benne 'I hope that', responses activated the conceptual domains barátságos 'friendly', kedélyes 'jovial' and közvetlen 'direct', among others, whereas the style of kéttucatnyit 'two dozen' was marked by such categories as formális 'formal', udvarias 'polite', közvetlen 'direct', and kedves 'kind'.

(2) Excerpt "B"

A: Oké. Második csoport?

'Okay. The second group?'

B: A megoldás? Hát mivel ugye elég sokszor hülyéskedik az órán, ezért én arra gondoltam, hogy jó megoldás lenne egy kicsit oltani. Mármint olyan szinten, hogy amikor így poénkodni próbál, akkor akkor például hogy ilyeneket, hogy "ühüm, tudsz még ilyen jó poént mondani?" Hogy egy kicsit így letörni a szarvát ilyen módon. 
'The solution? Well, as he screws around quite often during class, I thought that it'd be a good solution to slag him off. I mean, when he tries to crack jokes, then then to say things like "uhm, can you tell some other good jokes like this?" To take him down a peg this way.'

By contrast, in excerpt "B", certain constructions received greater stylistic markedness. A remarkable proportion of respondents (65\%) found the same construction, oltani 'to slag him off' the most crucial for the construal of style. Among respondents, several attributed stylistic markedness to this construction in terms of the overall formation of discourse (Factor 1), which is illustrated by the conceptual domains laza 'casual' (10), hétköznapi 'everyday' (6) and társalgási 'conversational' (5). Additionally, the majority of respondents highlighting oltani 'to slang him off' (14) labelled several folk categories which profile different socio-cultural factors. These expressions allow us to identify a typical co-occurrence between socio-cultural factors which is reflected by the category laza 'casual' from the Factor of Discourse (F1), informális 'informal' from the Factor of Situation (F2) and szleng 'slang' from the Factor of Language varieties (F5), as these conceptual domains co-occurred the most frequently. The same comments can be made on the second most salient construction, hülyéskedik 'he screws around' as well. Eighty-four percent of respondents highlighting hülyéskedik 'he screws around' marked oltani 'to slag him off' as well.

(3) Excerpt "C"

A: Hosszú lett, és aztán rájöttem, hogy basszus, de hát ezt sokkal egyszerübben is meg lehet csinálni.

'It was too complicated, and then I realised that, damn, I could've done it in a much more simple way.'

B: Így van. A kedvemért az egyszerüséget valahogy ügyesen definiáljuk!

'That's right. Please try to define this simplicity a bit more expertly.'

A: Igen. [nevetés] Mondjuk definiáljuk úgy, hogy hogy alacsonyabb iskolai tanulmányokbeli apparátussal.

'Yes. [laughter] Well, let's define it like like "with a less refined level of educational apparatus",

Categories reflecting style attributions support the conclusion that the style of excerpt " $\mathrm{C}$ " is heterogeneous. In this excerpt, two constructions proved to be stylistically decisive: one is basszus 'damn' (69\%), the other is apparátus 'apparatus' (36\%). Respondents who rated basszus 'damn' salient expressed their style attributions by the categories laza, hétköznapi 'casual, everyday' with regard to the overall formation of discourse (Factor 1), and közvetlen, informális 'direct, informal' in terms of the Factor of Situation (F2). At the same time, those highlighting apparátus 'apparatus' activated the opposite poles of these socio-cultural factors, marked by the conceptual domains tudományos, választékos 'scientific, sophisticated' (Factor 1) and formális, hivatalos 
'formal, official' (Factor 2). Furthermore, the fact that $82 \%$ of respondents highlighting apparátus 'apparatus' also found basszus 'damn' crucial for the stylistic character of excerpt "C" draws our attention to the heterogeneity of style. Additionally, those who highlighted the two above-mentioned constructions at the same time, pointed at an atypical co-occurrence between socio-cultural factors by their labels of style (e.g., közvetlen, barátságos, de egyben tudományos, szakmai is 'direct, friendly but scientific, professional at the same time') in 15 out of 18 cases.

Below, Table 2 summarizes the most salient expressions of the selected excerpts. Importantly, informants of the first questionnaire highlighted these constructions because their conceived social salience crucially informed style attributions. Consequently, the percentage values indicate the proportion of informants finding the particular construction as the most peculiar one to the stylistic construal of the given excerpt.

Table 2. Salient constructions in excerpts "A", "B" and "C"

(Highlighted by at least $10 \%$ of respondents)

\begin{tabular}{|c|c|c|c|c|c|}
\hline \multicolumn{2}{|c|}{$\begin{array}{c}\text { Excerpt "A" } \\
\text { (total number of respondents: } 74 \text { ) }\end{array}$} & \multicolumn{2}{|c|}{$\begin{array}{c}\text { Excerpt "B" } \\
\text { (total number of respondents: } 57 \text { ) }\end{array}$} & \multicolumn{2}{|c|}{$\begin{array}{c}\text { Excerpt "C" } \\
\text { (total number of respondents: } 61 \text { ) }\end{array}$} \\
\hline bizom benne & $34 \%$ & oltani & $65 \%$ & basszus & $69 \%$ \\
\hline 'I hope that' & & 'to slag him off' & & 'damn' & \\
\hline kéttucatnyit & $24 \%$ & hülyéskedik & $33 \%$ & apparátus & $36 \%$ \\
\hline 'two dozen' & & 'he screws around' & & 'apparatus' & \\
\hline problémás pontok & $22 \%$ & letörni a szalvát & $19 \%$ & mondjuk & $16 \%$ \\
\hline 'problematic points' & & 'to take him down a peg' & & 'well' & \\
\hline tetszöleges & $19 \%$ & oké & $18 \%$ & definiáljuk & $13 \%$ \\
\hline 'arbitrary' & & 'okay' & & 'define' & \\
\hline jegyzék & $19 \%$ & akkor akkor például & $16 \%$ & & \\
\hline \multirow[t]{5}{*}{ 'list' } & & 'then then ... like' & & & \\
\hline & & mánmint olyan szinten & $12 \%$ & & \\
\hline & & 'I mean' & & & \\
\hline & & poénkodik & $11 \%$ & & \\
\hline & & 'crack jokes' & & & \\
\hline
\end{tabular}

Nonetheless, the first questionnaire did not yield detailed results about the stylistic markedness or unmarkedness of particular constructions. One reason is that informants primarily reflected on the style of the entire excerpt, not on the stylistic function of particular constructions. Secondly, the first survey made it hard for us to decide whether respondents had highlighted expressions which were truly salient for the construal of style or else expressions whose construal was typical for the situation at hand (but salient to them from an "external perspective" as it were). Therefore, we used a second questionnaire to find out more about the stylistic markedness of particular linguistic constructions as well as the socio-cultural factors under study.

\subsection{Socio-cultural factors in style attributions}

In the second survey, we examined how different socio-cultural factors characterize particular excerpts, and what may characterize the social salience of linguistic con- 
structions processed in their discursive context. We measured the style of particular excerpts and the stylistic markedness of linguistic constructions (the two most salient constructions of each excerpt, see Table 2) on scales whose extremes were labelled by folk categories reflecting style attributions. Building on the results of the first survey (adjusting formulation to distinctive features of each excerpt), we measured the functioning of the following socio-cultural factors: (F1) attitude to the overall formation of discourse, (F2) attitude to the discourse partner, (F3) value-based attitude to the topic of the discourse, (F5) attitude to the norms of the register of discourse. Nevertheless, two explanatory comments on the scales need to be added. Firstly, since in the first questionnaire, a considerable number of intuitive expressions profiling the Factor of Discourse (F1) highlighted the speaker's attitude to the overall formation of discourse from a prescriptive perspective (e.g., pongyola 'sloppy', igényes 'fastidious'), we set two scales for Factor 1: a descriptive and a prescriptive one (see Figures 3a-b). Secondly, we did not draw a scale for the Factor of Time (F4), as the results of the first survey reveal that this socio-cultural factor did not play a decisive role in the stylistic construal of our excerpts. In the present paper, we confine the demonstration of results to the three previously cited excerpts, concentrating on two Factors in each excerpt.

In responses given to excerpt "A", the mid-points (the stylistically unmarked, neutral domain) of 5-point scales received the most rates with respect to each socio-cultural factor. This tendency was not substantially influenced by whether or not the respondent received a version of the questionnaire in which we had highlighted the most salient construction.

\section{Socio-cultural factor: Discourse (F1)}

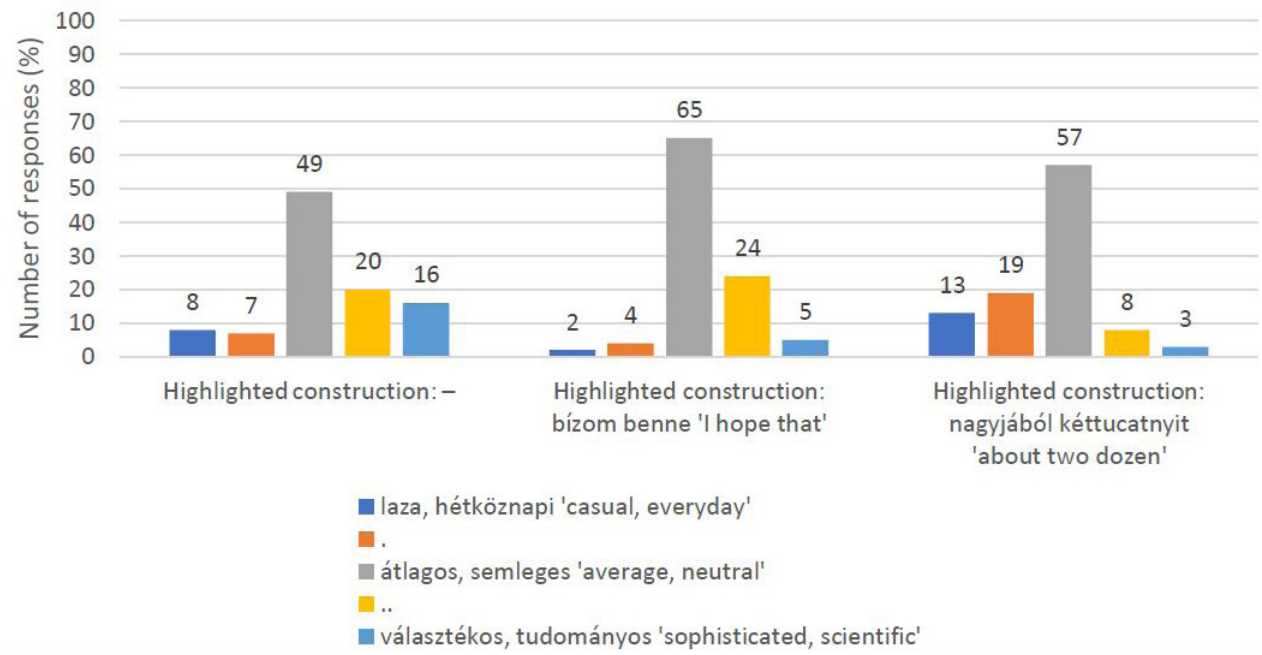

Figure 2a. Attitude to the overall formation of discourse (Factor 1) in excerpt "A" 
Figure 2a demonstrates that when we asked informants about the style of the excerpt "generally", almost half of them (49\%) marked the mid-point of the descriptive scale laza, hétköznapi - átlagos, semleges - választékos, tudományos 'casual, everyday - average, neutral - sophisticated, scientific'. When the question focused on the stylistic markedness of bizom benne 'I hope that' in its discursive context even more votes were produced in the neutral domain: $65 \%$ of respondents marked the mid-point, and $24 \%$ rated the domain between átlagos, semleges 'average, neutral' and absolutely választékos, tudományos 'sophisticated, scientific'. Similar remarks can be made about the stylistic markedness of nagyjából kéttucatnyit 'about two dozen': the neutral domain definitely dominates among the answers ( $57 \%$ of informants rated it). Consequently, the two most salient constructions of the first questionnaire proved to be stylistically unmarked according to the majority of informants in the second survey - with regard to the overall formation of discourse (Factor 1) from a descriptive perspective. However, this does not imply that the results of the two surveys contradict each other. Importantly, the results of the first survey suggest that in rather neutral excerpts, fewer respondents highlight the same construction as the most salient one (see Section 4.2.).

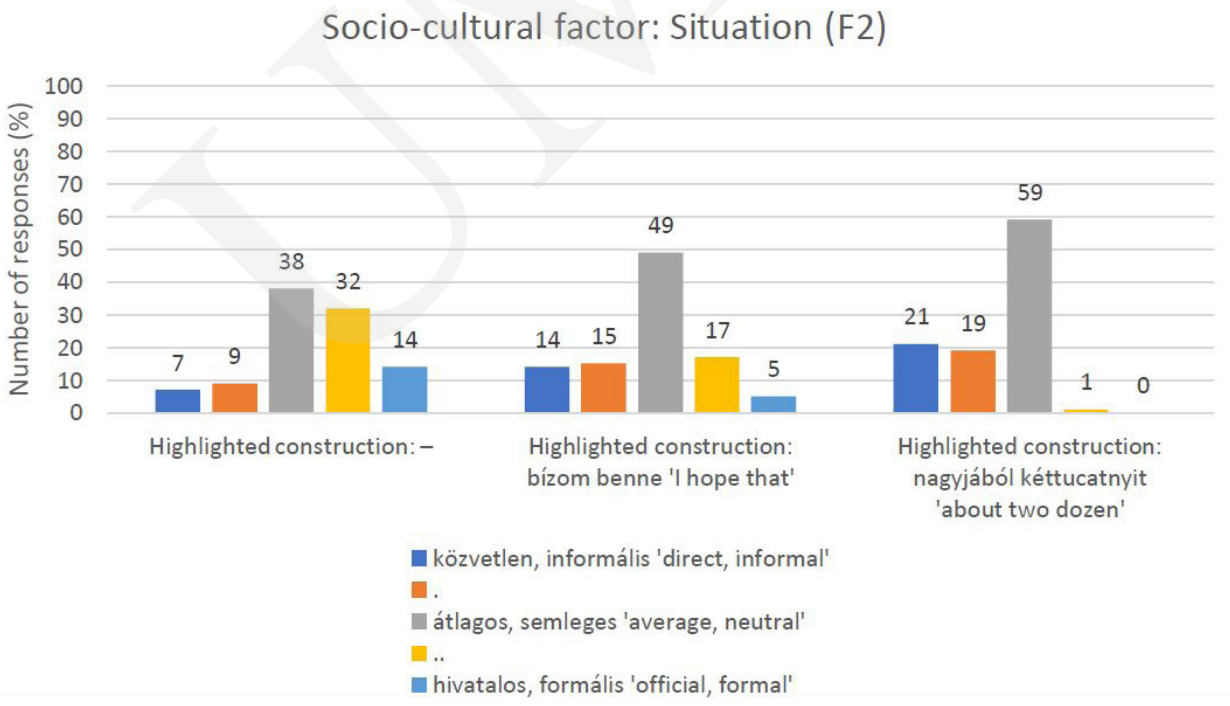

Figure 2b. Attitude to the discourse partner (Factor 2) in excerpt "A"

Considering the speaker's attitude to her discourse partner (Factor 2), results of excerpt "A" produced tendencies akin to results concerning attitude to the overall formation of discourse (Factor 1). The majority of informants (38\%) rated the "general" style of this excerpt átlagos, semleges 'average, neutral'. Moreover, a relatively high number of respondents (32\%) regarded the style of the entire excerpt rather hivatalos, formális 'official, formal', although they stopped short of marking the extreme of the scale. Figure $2 \mathrm{~b}$ also presents data about the stylistic markedness of bizom benne 'I hope that' 
and nagyjából kéttucatnyit 'about two dozen': the number of respondents indicating the mid-point was decisively higher (49\% and 59\%, respectively). Importantly, when the question concerned the whole excerpt, ratings shifted towards the extreme marked by hivatalos, formális 'official, formal', while the opposite extreme (közvetlen, informális 'direct, informal') was preferred when bizom benne 'I hope that' and nagyjából kéttucatnyit 'about two dozen' were highlighted.

The results of excerpt " $B$ " reinforce tendencies already indicated by the first survey: a strong shift can be registered to one extreme of the scales which is labelled by laza, hétköznapi 'casual, everyday' regarding the Factor of Discourse (F1), közvetlen, informális 'direct, informal' regarding the Factor of Situation (F2), and szleng 'slang' regarding the Factor of Language varieties (F5). Essentially, the above tendency was more dominant when the questionnaire addressed the stylistic markedness of oltani 'to slag him off'. Considering the Factor of Value (F3), a clear shift towards the extreme humoros, ironikus 'humorous, ironic' was detected, yet the domain átlagos, semmilyen 'average, none' received the highest number of ratings.

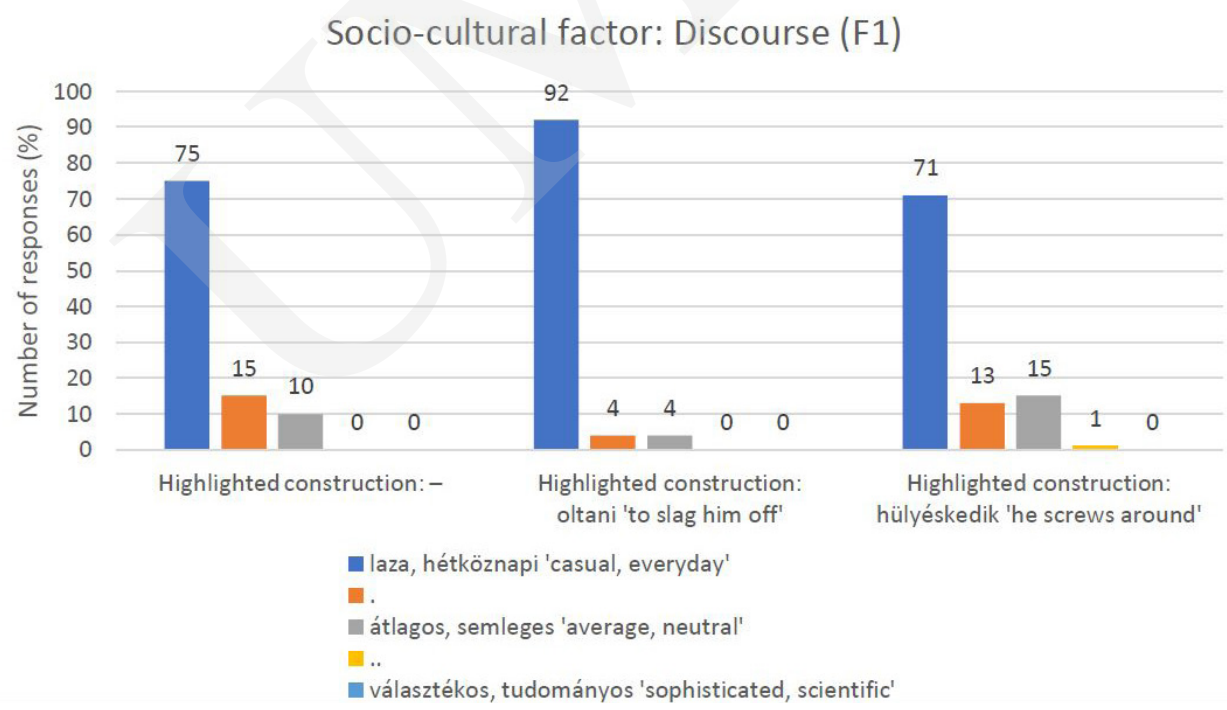

Figure 3a. Attitude to the overall formation of discourse (Factor 1) from a descriptive perspective in excerpt "B"

When our question addressed the style of excerpt "B" globally, 75\% of informants rated it absolutely laza, hétköznapi 'casual, everyday'. More unequivocal results were revealed in the version addressing the social salience of oltani 'to slag him off': $92 \%$ of respondents found its style absolutely laza, hétköznapi 'casual, everyday'. The stylistic markedness of hülyéskedik 'he screws around' bears great resemblance to that of the excerpt as a whole, with $71 \%$ of informants regarding this construction absolutely laza, hétköznapi 'casual, everyday'. Remarkably, the opposite extreme of the scale was marked by only one informant (1\%). 
Pobrane z czasopisma New Horizons in English Studies http://newhorizons.umcs.pl Data: 26/04/2023 15:05:58

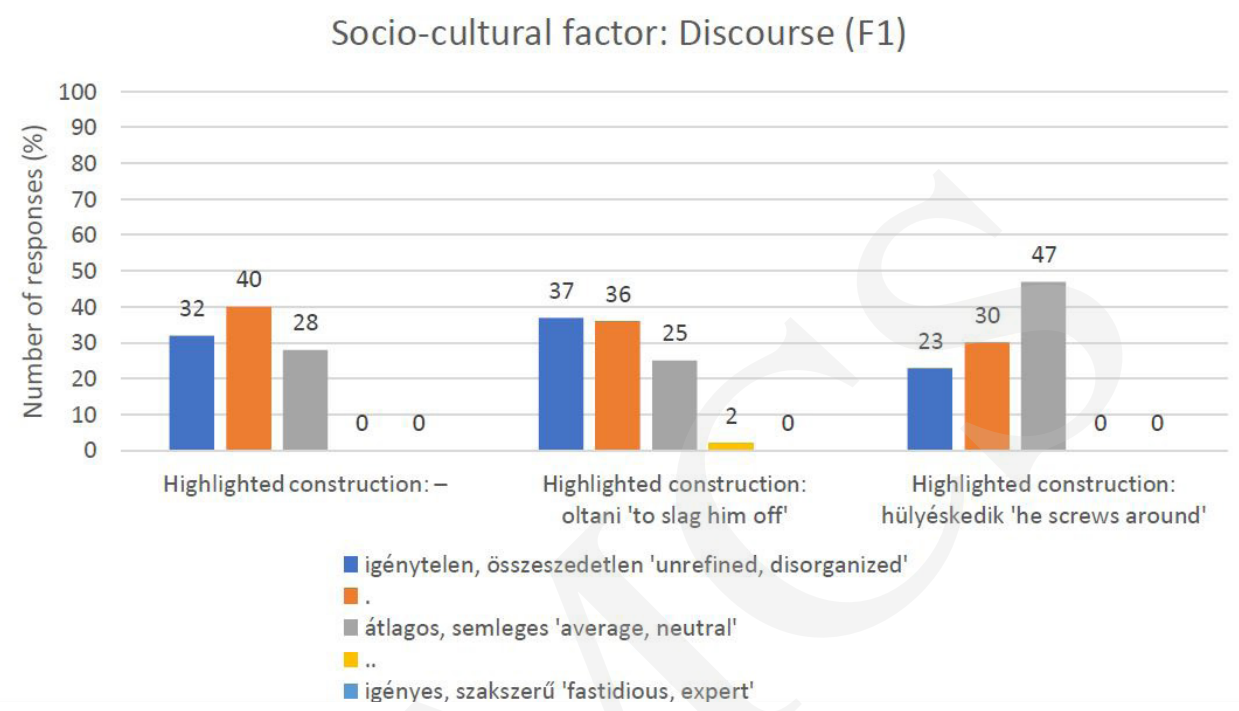

Figure 3b. Attitude to the overall formation of discourse (Factor 1) from a prescriptive perspective in excerpt "B"

Results from the first questionnaire suggest that everyday language use might be characterized by an attitude evaluating construal positively or negatively, as canonized by the classical rhetorical tradition in the dichotomic system of stylistic virtues and vices. On this basis, we introduced the scale igénytelen, összeszedetlen - átlagos, semleges - igényes, szakszerü 'unrefined, disorganized - average, neutral - fastidious, expert', applying it to the overall formation of discourse (Factor 1). Similarly to descriptive attitude (see Figure 3a), responses prioritize the left pole of the scale. However, a noticeable difference also emerges: the evaluations do not strikingly shift towards the extreme igénytelen, összeszedetlen 'unrefined, disorganized' (see Figure 3b).

Results concerning excerpt " $\mathrm{C}$ " draw attention to the heterogeneity of style. Specifically, according to scales addressing different socio-cultural factors, the number of ratings was more balanced at particular domains of each scale when informants had to evaluate the style of the excerpt globally. Meanwhile, in versions with the two most salient constructions highlighted (basszus 'damn', alacsonyabb iskolai tanulmányokbeli apparátussal 'with a less refined level of educational apparatus'), votes respectively shifted towards the opposite extremes of the scales. All these results remind us of the heterogeneity of style in excerpt " $\mathrm{C}$ ". At the same time, the results also indicate the greater stylistic markedness of basszus 'damn' (compared to apparátus 'apparatus'), as the extremes of the relevant scales were rated by a higher number of respondents. 
Pobrane z czasopisma New Horizons in English Studies http://newhorizons.umcs.pl Data: 26/04/2023 15:05:58

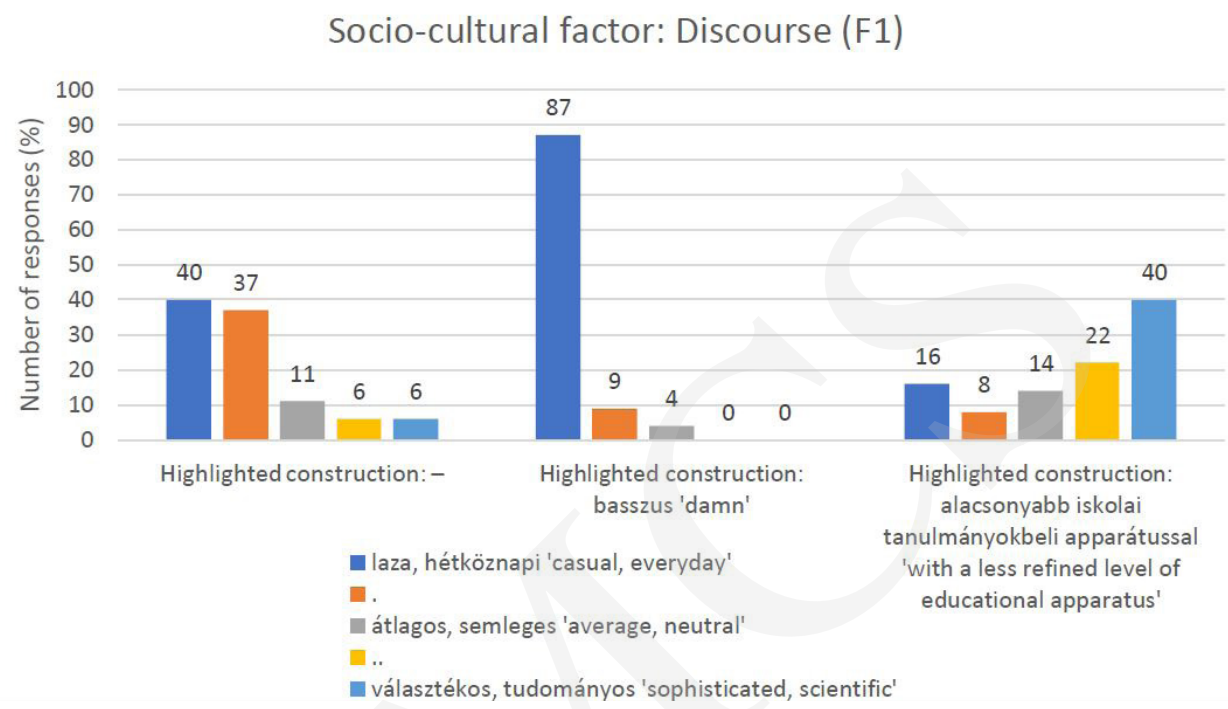

Figure 4a. Attitude to the overall formation of discourse (Factor 1) in excerpt "C"

Excerpt "C" was evaluated as laza, hétköznapi 'casual, everyday' in terms of the overall formation of discourse (F1) by the majority of respondents: $37 \%$ found its style rather and 40\% absolutely laza, hétköznapi 'casual, everyday' (see Figure 4a). The high degree of social salience of basszus 'damn' is detected more clearly: $87 \%$ of informants rated it absolutely, and 9\% rather laza, hétköznapi 'casual, everyday'. Moreover, basszus 'damn' did not receive any rating on the opposite extreme, while

\section{Socio-cultural factor: Language variety (F5)}

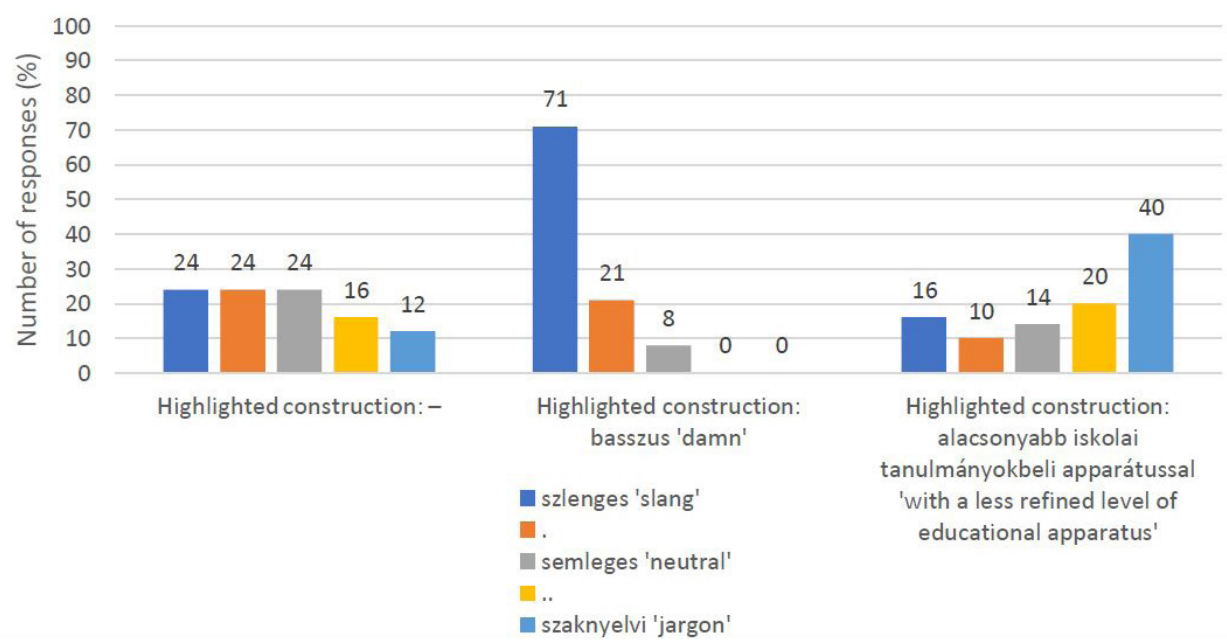

Figure 4b. Attitude to the norms of the register of discourse (Factor 5) in excerpt " $\mathrm{C}$ " 
alacsonyabb iskolai tanulmányokbeli apparátussal 'with a less refined level of educational apparatus' was evaluated by $40 \%$ of respondents as absolutely választékos, tudományos 'sophisticated, scientific', but was also considered absolutely laza, hétköznapi 'casual, everyday' by $16 \%$ of informants. This phenomenon might be explained by the potential ironic interpretation of the utterance containing the construction.

In excerpt "C", the parameter of attitude to the norms of the register of discourse (F5) produces similar results to attitude to the overall formation of discourse (F1), with the slight difference that the extreme szlenges 'slang' received a smaller proportion of ratings both in terms of the style of excerpt " $\mathrm{C}$ " in general and the stylistic markedness of baszszus 'damn' in particular. Basszus 'damn' was rated absolutely szlenges 'slang' by $71 \%$ of informants, but absolutely laza, hétköznapi ‘casual, everyday' by $87 \%$. However, alacsonyabb iskolai tanulmányokbeli apparátussal 'with a less refined level of educational apparatus' produces almost completely similar data in the Factor of Language varieties (F5).

\section{Conclusions}

The study described in this paper makes the case for considering the speaker's socio-cultural situatedness - for example, understanding that the speaker talks to her teacher as a student (or to her student(s) as a teacher) about a scientific topic in a university seminar - as a context-dependent vantage point for style attribution. Specifically, the speaker's socio-cultural situatedness allows participants of the joint attentional scene to adjust their intersubjective construal of experiences to accessible socially grounded and culture-specific expectations concerning adequate construal of style.

In our empirical study, we initiated an investigation of style attribution on the basis of intuitive, everyday labels of style - understood as folk categories - which were elicited in the form of metapragmatic reflections in the first questionnaire. On the basis of discourse excerpts, informants reflected on the speaker's socio-cultural situatedness via these intuitive, everyday expressions labelling style. The results support the following general statements.

Concerning the attested everyday, intuitive labels of style giving evidence of the speaker's socio-cultural situatedness (RQ1), we can state that these expressions profile different conceptual domains of socio-cultural situatedness, characteristically with polarized arrangements (see Figure 1). Folk categories reflecting style attributions form bundles whose arrangement can be described by the more abstract, heuristic scientific categories of socio-cultural factors (see Table 1). These socio-cultural factors are the speaker's attitude to the overall formation of discourse (Factor 1), to the discourse partner (Factor 2), to the value of the topic of the discourse (Factor 3), to the temporality of linguistic constructions (Factor 4) and to the norms of the register of discourse (Factor 5). On the one hand, these factors are open, prototype-based categories; on the other hand, particular intuitive labels of style profile different conceptual components of the socio-cultural factor in hand. 
The results pertain to different factors of the speaker's socio-cultural situatedness foregrounded by everyday expressions reflecting style and the accompanying conceptual domains (RQ2), and suggest the following tendencies. A general tendency characteristic of both particular excerpts and their totality is that by using folk categories reflecting style attributions, informants most frequently foregrounded the speaker's attitude to the overall formation of discourse and to the discourse partner from among different socio-cultural factors. Everyday labels of style profiled a wide variety of conceptual domains in terms of the two factors mentioned above, with some of them occurring considerably frequently. Additional foregrounded factors were the factor of the speaker's value-based attitude to the topic of the discourse and the factor of the speaker's attitude to the norms of the register of discourse, the latter occurring with reasonably fewer mentions and less diverse conceptual elaborateness. Finally, the speaker's attitude to the temporality of linguistic constructions - in accordance with the basic character of the primary linguistic input of the empirical study - was rarely highlighted by responses (see Table 2).

In our study, we also examined the effect of particular socio-cultural factors on the stylistic character of the discourse (i.e., the emergence of the stylistic character of discourse) and the stylistic markedness of the applied linguistic constructions (RQ3). The results highlight some tendencies that are clearly manifested with respect to particular socio-cultural factors. More specifically, the extent to which the construal of style is foregrounded and a linguistic construction becomes stylistically marked in a discourse can be plausibly treated as a matter of degree. Based on the second questionnaire, a concluding statement can be made about assessing the stylistic character of a particular discourse and the stylistic markedness of linguistic constructions: they produce remarkably converging results among informants, with slight or considerable shifts towards certain conceptual domains of socio-cultural factors and with a higher or lower number of ratings on particular domains. Generally, when scales addressed the style of excerpts globally - and not the stylistic markedness of a given construction - there were less prominent, less explicit shifts of ratings towards one or another extreme, or towards the mid-points of scales.

The two-phase empirical study also tested the social salience and the associated stylistic markedness of linguistic constructions (RQ4). Evaluations on the style of excerpts globally and on the stylistic markedness of linguistic constructions considered salient by respondents of the first questionnaire form peculiar patterns. On the one hand, we may conclude that socio-cultural factors show typical co-occurrences (casual, direct, humorous, unrefined, slang vs. neutral vs. sophisticated, official, solemn, fastidious, jargon), even if rates do not shift towards particular extremes (or towards domain neutral) to the same degree. On the other hand, during the emergence of the stylistic character of a discourse, a key role may be attributed to socially salient, i.e. stylistically marked constructions. Results of the second questionnaire also suggest that when informants had to rate excerpts globally, the style of those excerpts proved to be remarkably salient which contained constructions of a greater degree of stylistic markedness. 
Finally, it is worth noting that the style of a given excerpt was much more homogeneously evaluated by informants when the excerpt contained salient linguistic constructions showing stylistic markedness on extremes in the same direction. By contrast, when an excerpt contained several salient constructions with stylistic markedness on extremes in the opposite directions, evaluations were much more heterogeneous. Hence, we may conclude that homogeneity and heterogeneity of style are closely linked to socio-cultural attitudes and the stylistic markedness of employed linguistic constructions.

\section{Acknowledgments}

We would like to offer our special thanks to the anonymous reviewers for their insightful comments and suggestions on an earlier version of the article. We would also like to thank the editors for carefully reading our manuscript and advising us on how to refine it.

Our study was supported by the Thematic Excellence Programme of National Research, Development and Innovation Office (Hungary).

\section{References}

Barlow, Michael, and Suzanne Kemmer ed. 2000. Usage based models of language. Stanford, California: CSLI Publications.

Bednarek, Monika. 2011. "Approaching the Data of Pragmatics." In Foundations of Pragmatics, ed. Wolfram Bublitz, Andreas H. Jucker, and Klaus P. Schneider, 537-560. Berlin, Boston: Walter de Gruyter.

Croft, William. 2009. "Towards a Social Cognitive Linguistics." In New Directions in Cognitive Linguistics, ed. Vyvyan Evans, and Stephanie Poursel, 395-420. Amsterdam: John Benjamins.

Frank, Roslyn M. 2008. "Introduction: Sociocultural situatedness." In Body, Language, and Mind. Volume 2: Sociocultural Situatedness, ed. Roslyn M. Frank, René Dirven, Tom Ziemke, and Enrique Bernández, 1-18. Berlin, New York: Mouton de Gruyter.

Langacker, Ronald W. 1987. Foundations of Cognitive Grammar. Theoretical Prerequisites, Volume 1. Stanford: Stanford University Press.

Langacker, Ronald W. 2008. Cognitive Grammar. A Basic Introduction. Oxford: Oxford University Press.

Sanders, José, and Wilbert Spooren. 1997. "Perspective, Subjectivity, and Modality from a Cognitive Point of View." In Discourse and Perspective in Cognitive Linguistics, ed. Wolf-Andreas Liebert, Gisela Redeker, and Linda Waugh, 85-112. Amsterdam, Philadelphia: John Benjamins. 
Schmid, Hans-Jörg. 2007. CEntrenchment, Salience, and Basic Levels.” In The Oxford Handbook of Cognitive Linguistics, ed. Dirk Geeraerts, and Herbert Cuyckens, 117-138. Oxford: Oxford University Press.

Schmid, Hans-Jörg, and Günther, Franziska 2016. "Towards a Unified Socio-Cognitive Framework for Salience in Language." Frontiers in Psychology 7: 1110.

Sharifian, Farzad. 2008. "Distributed, Emergent Cultural Cognition, Conceptualisation and Language." In Body, Language, and Mind. Volume 2: Sociocultural Situatedness, ed. Roslyn M. Frank, René Dirven, Tom Ziemke, and Enrique Bernández, 109-136. Berlin, New York: Mouton de Gruyter.

Sharifian, Farzad 2017. Cultural Linguistics. Amsterdam, Philadelphia: John Benjamins Publishing Company.

Sinha, Chris. 2014. "Niche Construction and Semiosis: Biocultural and Social Dynamics." In The Social Origins of Language, ed. Daniel Dor, Chris Knight, and Jerome Lewis, 31-46. Oxford: Oxford University Press.

Smith, Eliot R., and Diane M. Mackie. 2000. Social Psychology. Philadelphia: Psychology Press.

Tannen, Deborah. 2005. Conversational Style: Analyzing Talk among Friends. Oxford: Oxford University Press.

Tátrai, Szilárd. 2013. "Attitude, Comparison, and Relation in Style. Remarks on the Socio-Cultural Factors of Style.” Studia Linguistica Hungarica 28: 21-36.

Tolcsvai Nagy, Gábor. 2005. A Cognitive Theory of Style. Metalinguistica 17. Frankfurt am Main: Peter Lang.

Tolcsvai Nagy, Gábor. 2013. "The Cognitive Linguistic Foundations of the Socio-Cultural Factors of Style." Studia Linguistica Hungarica 28: 7-20.

Tomasello, Michael. 1999. The Cultural Origins of Human Cognition. Cambridge MA: Harvard University Press.

Verhagen, Arie. 2007. "Construal and Perspectivization." In The Oxford Handbook of Cognitive Linguistics, ed. Dirk Geeraerts, and Hubert Cuyckens, 48-81. Oxford: Oxford University Press.

Verschueren, Jef. 1999. Understanding Pragmatics. London, New York, Sydney, Auckland: Edward Arnold.

Verschueren, Jef. 2000. "Notes on the Role of Metapragmatic Awareness." Pragmatics 10: 439-456.

Verschueren, Jef, and Frank Brisard. 2009. “Adaptability.” In Key Notions for Pragmatics. Handbook of Pragmatics Highlights 1, ed. Jef Verschueren, and Jan-Ola Östman, 28-47. Amsterdam, Philadelphia: John Benjamins.

Zlatev, Jordan 1997. Situated Embodiment: Studies in Spatial Semantics. Stockholm: Gotab.

Zlatev, Jordan 2014. "The Co-evolution of Human Intersubjectivity, Morality, and Language." In The Social Origins of Language. Studies in the Evolutions of Language. ed. Daniel Dor, Chris Knight, and Jerome Lewis, 249-266. Oxford: Oxford University Press. 